\title{
Cold tolerance in terrestrial invertebrates inhabiting subterranean habitats
}

\author{
Tone Novak $^{1 *}$, Nina Šajna ${ }^{1}$, Estera Antolinc $^{2}$, Saška Lipovšek ${ }^{1,3}$, Dušan Devetak ${ }^{1}$, \\ and Franc Janžekovič ${ }^{1}$
}

\begin{abstract}
${ }^{1}$ Department of Biology, Faculty of Natural Sciences and Mathematics, University of Maribor, Koroška cesta 160, SI-2000-Maribor, Slovenia ${ }^{2}$ Elementary School, Ptujska cesta 30, SI-3252 Rogatec, Slovenia

${ }^{3}$ Department of Cell Biology, Faculty of Medicine, University of Maribor, Slomškov trg 15, SI-2000-Maribor, Slovenia
\end{abstract}

\begin{abstract}
Most organisms are able to survive shorter or longer exposure to sub-zero temperatures. Hypothetically, trogloxenes characterized as not adapted, and troglophiles as not completely adapted to thermally stable subterranean environment, have retained or partially retained their ability to withstand freezing, while most troglobionts have not. We tested this hypothesis experimentally on 37 species inhabiting caves in Slovenia, analyzing their lower lethal temperatures in summer and winter, or for one season, if the species was not present in caves during both seasons. Specimens were exposed for $12 \mathrm{hrs}$ to $1^{\circ} \mathrm{C}$-stepwise descending temperatures with $48 \mathrm{hr}$ breaks. In general, the resistance to freezing was in agreement with the hypothesis, decreasing from trogloxenes over troglophiles to troglobionts. However, weak resistance was preserved in nearly all troglobionts, which responded in two ways. One group, withstanding freezing to a limited degree, and increasing freezing tolerance in winter, belong to the troglobionts inhabiting the superficial subterranean habitats. The other group, which equally withstand freezing in summer and winter, inhabit deep subterranean or other thermally buffered subterranean habitats. Data on cold resistance can thus serve as an efficient additional measure of adaptation to particular hypogean environments.
\end{abstract}

Keywords: Cold resistance; Slovenia; trogloxenes; troglophiles; troglobionts

Received 24 October 2013; Revised 26 March 2014; Accepted 7 April 2014

Citation: $\quad$ Novak T., Šajna N., Antolinc E., Lipovšek S., Devetak D. and Janžekovič F., 2014. Cold tolerance in terrestrial invertebrates inhabiting subterranean habitats. International Journal of Speleology, 43 (3), 265-272. Tampa, FL (USA) ISSN 0392-6672 http://dx.doi.org/10.5038/1827-806X.43.3.3

\section{INTRODUCTION}

Soon after the description of the leiodid beetle Leptodirus hochenwartii Schmidt, 1832 from the cave Postojnska jama-the first arthropod with conspicuous adaptation for living in hypogean habitats-intensive discussion began on the adaptation and ecology of animal species in the subterranean environment. Many ecological classifications of these organisms have been proposed, each of them being in particular restrained by the limited knowledge of species ecophysiology (Sket, 2008), and most of them burdened with the author's subjective judgments. Though not universally accepted (Desutter-Grancolas, 1999), the classification established by Schiner (1854) and Racovitza (1907) is sufficiently informative for many purposes in subterranean ecology and evolution (Boutin, 2004). It considers the three main ecological groups of animals in hypogean habitats: 1) Trogloxenes are the least adapted for living in the subterranean environment; they exhibit no morphological adaptation and do not complete their life cycle there. 2) Troglophiles alternate between the epigean and hypogean habitats or live permanently in subterranean habitats; they show some moderate adaptation, such as partly reduced eyes and adaptations to compensate for the lack of visual orientation. Some among these do not complete their life cycle underground, while others do. 3) Troglobionts complete their life cycle in a hypogean environment, and most of them clearly show troglomorphic characteristics, like eyelessness and depigmentation. In contrast to the frequent preference for these three ecological groups, Novak et al. (2012) found that, on the one hand, trogloxenes and troglophiles together represent a group of variously adapted species, rather than two ecologically clearly separated categories, and, on the other hand, troglobionts divide into two strictly separated subgroups.

Invertebrates are ectothermal and at their critical thermal minimum they enter chill-coma, where neuromuscular transmission and movement cease 
(Bowler \& Terblanche, 2008; MacMillan \& Sinclair, 2011). After thawing, they reactivate from this reversible state, or-in cases where they have exceeded their lower thermal lethal minimumdie. During late spring and early summer frosts, such recoveries or deaths are also usual in some species which periodically inhabit caves (Novak et al., 2004).

One possible measure to determine cold resistance is the supercooling point (SCP), which is the lowest temperature an animal reaches before freezing (Lee, 2010); however, the ecological validity of the SCP may sometimes be ambiguous (Renault et al., 2002). Lower lethal temperatures (LLTs) are a more authentic measure of survival ability, usually expressed as $\mathrm{LT}_{50}$, which is the measure of temperature at $50 \%$ mortality of individuals exposed to temperatures below $0^{\circ} \mathrm{C}$ (Leather et al., 1995; Watanabe, 2002).

Response to below-zero temperatures is one such additional measure that enables a comparative insight on the general scale. The scarcity of evidence about LLTs in terrestrial animal residents in caves (Sacharov, 1930; Kirchner, 1973; Pullin \& Bale, 1986; Novak et al., 2004, 2007; Latella et al., 2008; Lencioni et al., 2010) does not provide consistent information on the topic, since these authors used a variety of experimental methods. Although not as stable as had previously been supposed, in the temperate zone, the temperature in the deep subterranean habitats like deep bedrock fissures and caves is close to the mean annual value in surface habitats (Luetscher \& Jeannin, 2004; Culver \& Pipan, 2009a, b). However, freezing is usually not expected in caves. Consequently, the highest tolerance to sub-zero temperatures is expected in the trogloxenes and diminishes over the troglophiles to the troglobionts, which are adapted to the deep subterranean habitats. In practice, some aquatic (Hervant \& Mathieu, 1997; Issartel, 2007; Colson-Proch et al., 2009) and terrestrial troglobionts (Peck, 1974; Latella et al., 2008; Lencioni et al., 2010) clearly show cold resistance. On the other hand, most Antarctic and Alpine species, which in their microhabitats are thermally buffered at above-zero temperatures, are intolerant to freezing (e.g., Zettel, 2000; Block, 2002; Elster \& Benson 2004; Lipovšek et al., 2004; Novak et al., 2004).

In this study, our aim was to establish to what extent the trogloxene-troglophile-troglobiont model fits with the expected decreasing resistance to temperatures below $0^{\circ} \mathrm{C}$ in selected central European and Dinaric species inhabiting caves. For this purpose we measured their LLTs in winter and summer, to detect eventual seasonal differences in the response. We also hypothesized that, within these species, the range of response to under-zero temperatures is widest in trogloxenes and diminish over troglophiles to troglobionts. Additionally, we tested whether, according to the LLTs, the presence of two troglobiont groups (shallow and deep sensu Novak et al., 2012) could be detected.

\section{MATERIALS AND METHODS}

\section{Sample collection}

Specimens of a representative series of 37 species divided among trogloxenes, troglophiles and troglobionts (Table 1) were selected for measurement of their LLTs. They were collected from 14 caves and abandoned mines (in the following text: caves) in Slovenia at altitudes of 365-760 m. Besides the two gastropod species, all the others were arthropods. The specimens were collected during two critical periods: in summer or in winter, or in both seasons if specimens were present in caves. In Amilenus and both Gyas species, individuals of various stages were present in summer (adults) and winter (nymphs), while adults, older and the younger larvae of both Troglophilus species occurred synchronically in caves. In principle, five individuals of each stage and sexdepending on the species-of non-protected species, and three individuals each of the protected species were collected for the investigation. For a few species, we used a smaller number of specimens due to collecting difficulties.

In 54 ecologically investigated caves in Slovenia measured air temperature profiles (details in Novak, 2005; Novak et al., 2004, 2012) were used to characterize habitat temperatures of the species studied. For the habitats for each species, we calculated the mean, minimal and maximal temperatures $\left(\mathrm{T}_{\text {mean }}\right.$, $\mathrm{T}_{\min }$ and $\mathrm{T}_{\max }$ ) to compare with the LLTs.

\section{Laboratory analyses}

The following protocol was arranged to measure LLTs and simulate repeated frosts in natural habitat. The LLT measurements were carried out in a precise thermostatic cooling chamber THK/V1-2020 (Elpromer, Slovenia) with a temperature adjustment of $\pm 0.1^{\circ} \mathrm{C}$, and a cooling/warming movement of $\sim 10^{\circ} \mathrm{C} / \mathrm{hr}$. Measurements started at $-2.0^{\circ} \mathrm{C}$ and were stopped at $-12.0^{\circ} \mathrm{C}$. Experimental individuals were placed in groups of up to five specimensdepending on their size and number-on a piece of wet paper in $2 \mathrm{dL}$ vessels moistened every $5^{\text {th }}$ day to prevent desiccation. After a two-day acclimation in a refrigerator at $6.0^{\circ} \mathrm{C}$, the vessels were placed in the cooling chamber. The specimens were exposed to a particular temperature for $12 \mathrm{hrs}$, afterwards kept for $48 \mathrm{hrs}$ in the refrigerator at $6.0^{\circ} \mathrm{C}$ and then exposed to a temperature $1.0^{\circ} \mathrm{C}$ lower. Specimens' condition was checked after $24 \mathrm{hrs}$ at $6.0^{\circ} \mathrm{C}$, when the eventual dead ones were removed. The procedure was repeated until all the specimens had died.

\section{Statistical analysis}

Specimens differing by sex and stage were first tested using the Mann-Whitney $\mathrm{U}$ test with a Bonferroni correction for two comparisons, and in Troglophilus neglectus where adults, older and younger larvae co-occurred, for six comparisons to analyze whether they differ in LLTs either in summer or winter (in the following: $s$ and $w$ ). There were no significant differences in any experimental species (adjusted $p$ value for sex: $p>0.025$, for T. neglectus: $p>0.008$ ) 
Table 1. Experimental species to determine LLTs. Biospeological categories: $\mathrm{x}$ trogloxene, $\mathrm{f}$ troglophile, $\mathrm{t}$ troglobiont. $w$ winter.

\begin{tabular}{|c|c|c|}
\hline Higher taxon & Family & Species \\
\hline Gastropoda & Helicidae & $\begin{array}{l}1 \times \text { Chilostoma (Josephinella) lefeburiana } \\
\quad \text { (A. Ferussac 1821) } \\
2 \times \text { Faustina illyrica (Stabile 1864) }\end{array}$ \\
\hline \multirow{2}{*}{ Oniscoidea } & \multirow{2}{*}{ Trichoniscidae } & 3 t Andronuscus stygius (Nemec 1897) \\
\hline & & 4 t Titanethes albus (C. Koch 1841) \\
\hline \multirow{4}{*}{ Araneae } & Agelenidae & 5 x Malthonica silvestris (L. Koch 1872) \\
\hline & Linyphiidae & $\begin{array}{l}6 \text { f Troglohyphantes diabolicus } \\
\text { (Deeleman Reinhold 1978) }\end{array}$ \\
\hline & Nesticidae & 7 x Nesticus cellulanus (Clerck 1757) \\
\hline & Tetragnathidae & $\begin{array}{l}8 \text { f Meta menardi (Latreille 1804) } \\
9 \text { x Metellina merianae (Scopoli 1763) }\end{array}$ \\
\hline \multirow{3}{*}{ Opiliones } & Sclerosomatidae & $\begin{array}{l}10 \mathrm{f} \text { Amilenus aurantiacus (Simon 1881) } \\
11 \times \text { Gyas annulatus (Olivier 1791) } \\
12 \times \text { Gyas titanus (Simon 1879) } \\
13 \times \text { Leiobunum rupestre (Herbst 1799) }\end{array}$ \\
\hline & Ischyropsalididae & $14 \mathrm{t}$ Ischyropsalis hadzii Roewer 1950 \\
\hline & Nemastomatidae & $\begin{array}{l}15 \text { x Paranemastoma bicuspidatum } \\
\quad \text { (C. L. Koch 1835) } \\
16 \text { x Paranemastoma quadripunctatum } \\
\quad \text { (Perty 1833) }\end{array}$ \\
\hline Microcoryphia & Machilidae & $17 \times$ Trigoniophthalmus alternatus (Silvestri 1904) \\
\hline Orthoptera & Rhaphidophoridae & $\begin{array}{l}18 \text { f Troglophilus cavicola (Kollar 1833), } \\
\text { w: adults + larvae } \\
19 \text { f Troglophilus neglectus (Krauss 1879), } \\
\text { w: adults + larvae }\end{array}$ \\
\hline \multirow{3}{*}{ Lepidoptera } & Geometridae & $20 \times$ Triphosa dubitata (Linnaeus 1758) \\
\hline & Noctuidae & 21 x Scoliopteryx libatrix (Linnaeus 1758) \\
\hline & Nymphalidae & $22 \times$ Aglais io (Linnaeus 1758) \\
\hline \multirow[t]{9}{*}{ Coleoptera } & Carabidae & 23 t Anophthalmus hitleri (Scheibl 1937) \\
\hline & & $\begin{array}{l}24 \mathrm{f} \text { Laemostenus (Antisphodrus) schreibersii } \\
\text { (Küster 1846) }\end{array}$ \\
\hline & Leiodidae & 25 t Aphaobiella tisnicensis (Pretner 1956) \\
\hline & & 26 t Aphaobius milleri alphonsi (Müller 1914) \\
\hline & & $27 \times$ Catops tristis (Panzer 1794) \\
\hline & & 28 t Ceuthmonocharis pusillus (Jeannel 1924) \\
\hline & & $\begin{array}{l}29 \text { t Ceuthmonocharis robici robici } \\
\text { (Ganglbauer 1899) }\end{array}$ \\
\hline & & $30 \times$ Choleva sturmi (Brisout 1863) \\
\hline & & 31 t Leptodirus hochenwartii (Schmidt 1832) \\
\hline Hymenoptera & Ichneumonidae & 32 x Diphyus quadripunctorius (Müller 1776) \\
\hline \multirow[t]{4}{*}{ Diptera } & Culicidae & 33 x Culex pipiens (Linnaeus 1758) \\
\hline & Heleomyzidae & $\begin{array}{l}34 \text { x Heleomyza (Heleomyza) cf. captiosa } \\
\text { (Gorodkov 1961) }\end{array}$ \\
\hline & Limoniidae & $\begin{array}{l}35 \times \text { Chionea (Sphaeconophilus) austriaca } \\
\quad \text { (Christian 1980) } \\
36 \times \text { Limonia nubeculosa (Meigen 1804) }\end{array}$ \\
\hline & Mycetophilidae & 37 f Speolepta leptogaster (Winnertz 1863), larvae \\
\hline
\end{tabular}

in either $s$ or $w$ season, allowing the combining of all specimens of a species irrespectively of sex and developmental stage in further analyses. For the analysis of trends in cold resistance, the species mean seasonal LLTs were calculated.

For 28 species with both the $s$ and the $w$ LLT measurements, a normalized plot of the $s$ vs. the $w$ LLTs was used for graphical analysis of species pre-classified within trogloxenes, troglophiles and troglobionts (Table 2). Seasonal differences among categories in their mean LLTs were tested separately for $s$ and $w$ using analysis of variance (ANOVA), followed by a post-hoc mean separation by the Tukey Honest Significant Difference (HSD) test for unequal sample sizes. The effect size was calculated using the formula $r=Z / \sqrt{ } N$; where $Z=$ Kolmogorov-Smirnov $Z$ and $\sqrt{ } \mathrm{N}=$ square root of the sample size (Field, 2009). To demonstrate general trends in the response differences among trogloxenes, troglophiles and troglobionts, we calculated the integrated distributional curves of the $s$ and $w$ LLTs for each category. To evaluate the possible presence of two categories of troglobionts (Novak et al. 2012), if such two groups exist also according to their $s$ and $w$ LLTs, we grouped Ischyropsalis hadzii, Anophthalmus hitleri, Ceuthmonocharis pusillus, and $C$. robici robici as previously recognized shallow subgroup and Andronuscus stygius, Titanethes albus, Aphaobiella tisnicensis, and Leptodirus hochenwartii as deep subgroup for further detailed comparisson. The agreement of the LLTs with air $\mathrm{T}_{\text {mean }}, \mathrm{T}_{\min }$ and $\mathrm{T}_{\max }$ at the settled sites within the 54 caves was tested using the correlation analysis. The data analysis was carried out with the statistical software SPSS 21.0.

\section{RESULTS}

Among the 37 species under study, 28 were collected from caves and tested for LLTs in $s$ and $w$, five only in $s$ and four only in $w$ (Table 2).

\section{Seasonal differences in LLTs}

Seasonal differences between $s$ and $w$ LLTs of individual species varied from non-significant to highly significant (Table 2). Most species could equally withstand $s$ and $w$ LLTs, while a few were more resistant to $s$ than to $w$ freezing, and the reverse for a few other species. On average, the LLTs differed by less than $1^{\circ} \mathrm{C}$ between the seasons. Only a few taxa exhibited $\geq 1^{\circ} \mathrm{C}$ difference between the $s$ and the $w$ LLTs (Table 3 ). Within the groups, the $s$ and $w$ LLTs did not significantly differ in trogloxenes, but differed significantly in troglophiles (Mann-Whitney $U$ test, $\mathrm{U}=1269.5, \mathrm{p}=0.001$ ) and troglobionts (Mann-Whitney $\mathrm{U}$ test, $\mathrm{U}=842.5, \mathrm{p}<0.001)$. Their corresponding effect sizes were $0.045,0.289$ and 0.363 , respectively, i.e., increasing from non-existent in trogloxenes over small in troglophiles to medium in troglobionts.

\section{Differences in LLTs between the ecological groups}

The LLT range was the widest for the trogloxenes (s: $-2--12^{\circ} \mathrm{C} ; \quad w:-2--10$ ), and narrowed in the troglophiles (s: $-2--9 ; w:-2--9)$ and even more so in the troglobionts $(s:-2--5 ; w:-2--6)$. The resistance to freezing decreased from trogloxenes over troglophiles to troglobionts (Fig. 1). We obtained a statistically significant overall $\mathrm{F}$ test from the ANOVA for the mean LLTs in $s\left(\mathrm{~F}_{2,30}=6.97, \mathrm{p}=0.003\right)$. Posteriori testing showed significant differences between trogloxenes and troglobionts (HSD for unequal N, $\mathrm{p}=0.017$ ). Normalized results of the LLTs are shown in Fig. 2 together with the best fits of error function (Gauss error function) to the data.

\section{Subgroups in troglobionts}

All troglobionts under study exposed a certain degree of freezing tolerance, i.e., they withstood temperatures below $2^{\circ} \mathrm{C}$. A t test showed no significant difference between the $s$ and the $w$ LLTs in trogloxenes and troglophiles, while troglobionts demonstrated significantly lower LLTs in $w(t=4.26, d f=106$, $\mathrm{p}<0.001)$. The troglobionts classified in the shallow 
Table 2. Descriptive statistics of LLTs and ambient air T in 37 terrestrial invertebrate species inhabiting caves. Current numbers before species correspond to those in Table 1 and Fig. 1. Ns, Nw number of individuals in summer and winter; s-LLTs, w-LLTs summer and winter LLTs, and MannWhitney U test significance of $s$-LLTs vs. $w$-LLTs (ns non significant, ${ }^{*}<0.05,{ }^{* *}<0.01,{ }^{* * *}<0.001$, - analysis could not be performed); Ts caves and Tw caves summer and winter temperature in cave sections where species occurred.

\begin{tabular}{|c|c|c|c|c|c|c|c|c|c|c|c|}
\hline Species & $\mathrm{Ns} / \mathrm{Nw}$ & $\begin{array}{c}s \text {-LLTs } \\
\text { Mean } \pm \text { Sd } \\
\text { Min - Max }\end{array}$ & $\begin{array}{l}\text { Ts caves } \\
\text { Mean } \\
\text { Min - Max }\end{array}$ & $\begin{array}{c}\text { w-LLTs } \\
\text { Mean } \pm \text { Sd } \\
\text { Min - Max }\end{array}$ & $\begin{array}{l}\text { Tw caves } \\
\text { Mean } \\
\text { Min - Max }\end{array}$ & Species & $\mathrm{Ns} / \mathrm{Nw}$ & $\begin{array}{c}s \text {-LLTs } \\
\text { Mean } \pm \text { Sd } \\
\text { Min - Max }\end{array}$ & $\begin{array}{l}\text { Ts caves } \\
\text { Mean } \\
\text { Min - Max }\end{array}$ & $\begin{array}{c}w \text {-LLTs } \\
\text { Mean } \pm \text { Sd } \\
\text { Min - Max }\end{array}$ & $\begin{array}{c}\text { Tw caves } \\
\text { Mean } \\
\text { Min - Max }\end{array}$ \\
\hline $\begin{array}{l}1 \text { Chilostoma } \\
\text { lefeburiana }\end{array}$ & $\begin{array}{c}5 / 5 \\
*\end{array}$ & $\begin{array}{c}-3.6 \pm 0.5 \\
-4--3\end{array}$ & $\begin{array}{c}16.4 \\
15.1-17.6\end{array}$ & $\begin{array}{c}-4.8 \pm 0.4 \\
-5--4\end{array}$ & $\begin{array}{c}10.0 \\
9.5-10.7\end{array}$ & 20 Triphosa dubitata & $\underset{* *}{10 / 10}$ & $\begin{array}{c}-8.4 \pm 2.2 \\
-11--5\end{array}$ & $\begin{array}{c}11.8 \\
7.0-21.5\end{array}$ & $\begin{array}{c}-4.5 \pm 0.5 \\
-5--4\end{array}$ & $\begin{array}{c}2.3 \\
-4.8-9.1\end{array}$ \\
\hline 2 Faustina illyrica & $\begin{array}{c}5 / 5 \\
\mathrm{~ns}\end{array}$ & $\begin{array}{c}-4.2 \pm 0.4 \\
-5--4\end{array}$ & $\begin{array}{c}13.7 \\
8.5-22.0\end{array}$ & $\begin{array}{c}-4.2 \pm 0.4 \\
-5--4\end{array}$ & $\begin{array}{c}2.6 \\
-3.6-9.6\end{array}$ & 21 Scoliopteryx libatrix & $\begin{array}{c}1 / 10 \\
-\end{array}$ & -8 & $\begin{array}{c}11.6 \\
10.3-13.6\end{array}$ & $\begin{array}{l}-5.7 \pm 0.7 \\
-7--5\end{array}$ & $\begin{array}{c}3.4 \\
-3.2-11.4\end{array}$ \\
\hline $\begin{array}{l}3 \text { Andronuscus } \\
\text { stygius }\end{array}$ & $\begin{array}{c}10 / 10 \\
n s\end{array}$ & $\begin{array}{l}-3.5 \pm 0.5 \\
-4--3\end{array}$ & $\begin{array}{c}9.0 \\
9.0-9.1\end{array}$ & $\begin{array}{c}-3.8 \pm 0.4 \\
-4--3\end{array}$ & $\begin{array}{c}8.5 \\
8.5-8.5\end{array}$ & 22 Aglais io & $\begin{array}{c}2 / 3 \\
n s\end{array}$ & $\begin{array}{c}-9.0 \pm 0.0 \\
-9--9\end{array}$ & $\begin{array}{c}11.6 \\
8.7-14.4\end{array}$ & $\begin{array}{l}-9.0 \pm 1.0 \\
-10--8\end{array}$ & $\begin{array}{c}5.2 \\
5.2-5.2\end{array}$ \\
\hline 4 Titanethes albus & $\begin{array}{c}10 / 10 \\
\mathrm{~ns}\end{array}$ & $\begin{array}{c}-2.5 \pm 0.7 \\
-4--2\end{array}$ & $\begin{array}{c}8.6 \\
8.5-8.8\end{array}$ & $\begin{array}{c}-2.6 \pm 0.7 \\
-4--2\end{array}$ & $\begin{array}{c}9.0 \\
9.0-9.1\end{array}$ & 23 Anophthalmus hitleri & $2 / 2$ & $\begin{array}{c}-3.0 \pm 0.0 \\
-3--3\end{array}$ & $\begin{array}{c}8.3 \\
8.1-9.0\end{array}$ & $\begin{array}{c}-4.5 \pm 0.7 \\
-5--4\end{array}$ & $\begin{array}{c}8.2 \\
8.1-8.2\end{array}$ \\
\hline $\begin{array}{c}5 \text { Malthonica } \\
\text { silvestris }\end{array}$ & $\begin{array}{c}6 / 4 \\
\text { ns }\end{array}$ & $\begin{array}{c}-6.0 \pm 2.2 \\
-8--4\end{array}$ & $\begin{array}{c}11.7 \\
10.9-13.5\end{array}$ & $\begin{array}{c}-6.0 \pm 2.3 \\
-8--4\end{array}$ & $\begin{array}{c}2.2 \\
0.6-3.6\end{array}$ & $\begin{array}{l}24 \text { Laemostenus } \\
\text { schreibersii }\end{array}$ & $\begin{array}{c}3 / 8 \\
\mathrm{~ns}\end{array}$ & $\begin{array}{c}-4.7 \pm 0.6 \\
-5--4\end{array}$ & $\begin{array}{c}10.6 \\
5.7-18.3\end{array}$ & $\begin{array}{c}-4.9 \pm 0.4 \\
-5--4\end{array}$ & $\begin{array}{c}6.9 \\
5.2-9.0\end{array}$ \\
\hline $\begin{array}{c}6 \text { Troglohyphantes } \\
\text { diabolicus }\end{array}$ & $\begin{array}{c}7 / 4 \\
\mathrm{~ns}\end{array}$ & $\begin{array}{c}-7.6 \pm 1.6 \\
-9--5\end{array}$ & $\begin{array}{c}10.0 \\
8.2-21.3\end{array}$ & $\begin{array}{c}-7.8 \pm 1.3 \\
-9--6\end{array}$ & $\begin{array}{c}5.7 \\
-1.0-8.0\end{array}$ & $\begin{array}{c}25 \text { Aphaobiella } \\
\text { tisnicensis }\end{array}$ & $\begin{array}{c}6 / 6 \\
\text { ns }\end{array}$ & $\begin{array}{c}-3.0 \pm 0.0 \\
-3--3\end{array}$ & $\begin{array}{c}9.8 \\
9.8-9.9\end{array}$ & $\begin{array}{c}-3.2 \pm 0.4 \\
-4--3\end{array}$ & $\begin{array}{c}8.2 \\
8.0-9.0\end{array}$ \\
\hline 7 Nesticus cellulanus & $\begin{array}{c}10 / 10 \\
n s\end{array}$ & $\begin{array}{c}-7.3 \pm 1.3 \\
-9--6\end{array}$ & $\begin{array}{c}10.6 \\
8.1-14.8\end{array}$ & $\begin{array}{c}-7.0 \pm 1.2 \\
-9--6\end{array}$ & $\begin{array}{c}6.2 \\
3.1-9.6\end{array}$ & $\begin{array}{l}26 \text { Aphaobius milleri } \\
\text { alphonsi }\end{array}$ & -14 & & & $\begin{array}{l}-3.8 \pm 0.5 \\
-4--3\end{array}$ & $\begin{array}{c}7.5 \\
6.1-9.1\end{array}$ \\
\hline 8 Meta menardi & $\begin{array}{c}10 / 10 \\
\text { ns }\end{array}$ & $\begin{array}{l}-3.4 \pm 1.9 \\
-8--2\end{array}$ & $\begin{array}{c}12.6 \\
6.0-22.0\end{array}$ & $\begin{array}{l}-4.5 \pm 1.5 \\
-8--3\end{array}$ & $\begin{array}{c}4.4 \\
-4.5-11.4\end{array}$ & 27 Catops tristis & $4 /-$ & $\begin{array}{l}-6.0 \pm 0.8 \\
-7--5\end{array}$ & $\begin{array}{c}13.9 \\
6.9-17.1\end{array}$ & & \\
\hline 9 Metellina merianae & $\begin{array}{c}10 / 10 \\
n s\end{array}$ & $\begin{array}{c}-6.6 \pm 1.7 \\
-8--3\end{array}$ & $\begin{array}{c}12.5 \\
7.2-22.0\end{array}$ & $\begin{array}{c}-7.6 \pm 1.2 \\
-9--6\end{array}$ & $\begin{array}{c}2.4 \\
-3.6-11.4\end{array}$ & $\begin{array}{l}28 \text { Ceuthmonocharis } \\
\text { pusillus }\end{array}$ & $6 / 6$ & $\begin{array}{l}-3.8 \pm 0.4 \\
-4--3\end{array}$ & $\begin{array}{c}13.3 \\
12.2-15.5\end{array}$ & $\begin{array}{l}-5.2 \pm 0.4 \\
-6--5\end{array}$ & $\begin{array}{c}9.8 \\
9.8-9.9\end{array}$ \\
\hline $\begin{array}{l}10 \text { Amilenus } \\
\text { aurantiacus }\end{array}$ & $\begin{array}{c}10 / 10 \\
\mathrm{~ns}\end{array}$ & $\begin{array}{l}-4.4 \pm 0.5 \\
-5--4\end{array}$ & $\begin{array}{c}14.7 \\
7.2-21.5\end{array}$ & $\begin{array}{l}-4.8 \pm 0.4 \\
-5--4\end{array}$ & $\begin{array}{c}5.5 \\
-3.4-11.4\end{array}$ & 29 C. robici robici & $6 / 6$ & $\begin{array}{l}-3.2 \pm 0.4 \\
-4--3\end{array}$ & $\begin{array}{c}7.9 \\
5.7-14.8\end{array}$ & $\begin{array}{l}-4.8 \pm 0.4 \\
-5--4\end{array}$ & $\begin{array}{c}10.2 \\
9.8-10.5\end{array}$ \\
\hline $11 \mathrm{G}$. annulatus & $10 / 10$ & $\begin{array}{l}-4.7 \pm 0.5 \\
-5--4\end{array}$ & $\begin{array}{c}10.8 \\
10.8-10.8\end{array}$ & $\begin{array}{c}-2.6 \pm 0.5 \\
-3--2\end{array}$ & $\begin{array}{c}5.7 \\
2.1-8.4\end{array}$ & 30 Choleva sturmi & -12 & & & $\begin{array}{c}-4.0 \pm 0.0 \\
-4--4\end{array}$ & $\begin{array}{c}7.3 \\
7.3-7.7\end{array}$ \\
\hline 12 Gyas titanus & $\begin{array}{c}10 / 10 \\
\text { ns }\end{array}$ & $\begin{array}{l}-3.4 \pm 0.5 \\
-4--3\end{array}$ & $\begin{array}{c}10.4 \\
10.4-10.4\end{array}$ & $\begin{array}{c}-2.9 \pm 0.7 \\
-4--2\end{array}$ & $\begin{array}{c}2.0 \\
-3.5-6.5\end{array}$ & $\begin{array}{l}31 \text { Leptodirus } \\
\text { hochenwartii }\end{array}$ & $\begin{array}{l}6 / 6 \\
\text { ns }\end{array}$ & $\begin{array}{c}-3.8 \pm 1.0 \\
-5--3\end{array}$ & $\begin{array}{c}8.6 \\
8.5-8.8\end{array}$ & $\begin{array}{l}-4.3 \pm 0.5 \\
-5--4\end{array}$ & $\begin{array}{c}9.0 \\
9.0-9.1\end{array}$ \\
\hline $\begin{array}{l}13 \text { Leiobunum } \\
\text { rupestre }\end{array}$ & $10 /-$ & $\begin{array}{l}-3.4 \pm 0.5 \\
-4--3\end{array}$ & $\begin{array}{c}17.3 \\
12.9-21.5\end{array}$ & & & $\begin{array}{l}32 \text { Diphyus } \\
\text { quadripunctorius }\end{array}$ & $\begin{array}{c}-12 \\
-\end{array}$ & & & $\begin{array}{l}-7.5 \pm 0.7 \\
-8--7\end{array}$ & $\begin{array}{c}5.9 \\
2.6-8.4\end{array}$ \\
\hline $\begin{array}{l}14 \text { Ischyropsalis } \\
\text { hadzii }\end{array}$ & $6 / 6$ & $\begin{array}{c}-2.0 \pm 0.0 \\
-2--2\end{array}$ & $\begin{array}{c}8.7 \\
8.1-9.7\end{array}$ & $\begin{array}{l}-3.5 \pm 0.5 \\
-4--3\end{array}$ & $\begin{array}{c}8.6 \\
8.6-8.7\end{array}$ & 33 Culex pipiens & $\begin{array}{l}2 / 5 \\
\mathrm{~ns}\end{array}$ & $\begin{array}{l}-5.5 \pm 0.7 \\
-6--5\end{array}$ & $\begin{array}{c}15.7 \\
8.5-21.5\end{array}$ & $\begin{array}{l}-5.0 \pm 0.0 \\
-5--5\end{array}$ & $\begin{array}{c}4.1 \\
-2.5-9.9\end{array}$ \\
\hline $\begin{array}{c}15 \text { Paranemastoma } \\
\text { bicuspidatum }\end{array}$ & $\begin{array}{c}10 /- \\
-\end{array}$ & $\begin{array}{c}-3.8 \pm 0.4 \\
-4--3\end{array}$ & $\begin{array}{c}9.2 \\
7.7-12.2\end{array}$ & & & $\begin{array}{l}34 \text { Heleomyza cf. } \\
\text { captiosa }\end{array}$ & $5 /-$ & $\begin{array}{l}-10.4 \pm 1.8 \\
-12--8\end{array}$ & $\begin{array}{c}8.3 \\
8.0-8.4\end{array}$ & & $\begin{array}{c}5.2 \\
1.8-8.1\end{array}$ \\
\hline 16 P. quadripunctatum & $10 / 9$ & $\begin{array}{l}-4.3 \pm 0.5 \\
-5--4\end{array}$ & $\begin{array}{c}11.2 \\
9.8-12.5\end{array}$ & $\begin{array}{l}-7.4 \pm 0.7 \\
-8--6\end{array}$ & & 35 Chionea austriaca & $-/ 1$ & & & -7 & $\begin{array}{c}5.3 \\
1.6-8.9\end{array}$ \\
\hline $\begin{array}{l}17 \text { Trigoniophthalmus } \\
\text { alternatus }\end{array}$ & $10 / 10$ & $\begin{array}{l}-2.7 \pm 0.5 \\
-3--2\end{array}$ & $\begin{array}{c}8.1 \\
8.0-8.2 \\
\end{array}$ & $\begin{array}{l}-4.0 \pm 0.0 \\
-4--4\end{array}$ & $\begin{array}{c}4.1 \\
-3.6-9.6 \\
\end{array}$ & 36 Limonia nubeculosa & $\begin{array}{c}10 /- \\
-\end{array}$ & $\begin{array}{l}-4.7 \pm 0.5 \\
-5--4\end{array}$ & $\begin{array}{c}10.9 \\
5.8-22.0 \\
\end{array}$ & & \\
\hline $\begin{array}{l}18 \text { Troglophilus } \\
\text { cavicola }\end{array}$ & $10 / 20$ & $\begin{array}{l}-3.2 \pm 0.4 \\
-4--3\end{array}$ & $\begin{array}{c}12.3 \\
7.6-21.5\end{array}$ & $\begin{array}{l}-4.2 \pm 0.6 \\
-6--4\end{array}$ & $\begin{array}{c}6.9 \\
0.1-11.4\end{array}$ & 37 Speolepta leptogaster & $9 / 6$ & $\begin{array}{l}-4.1 \pm 0.6 \\
-5--3\end{array}$ & $\begin{array}{c}11.1 \\
7.1-20.4\end{array}$ & $\begin{array}{c}-2.0 \pm 0.0 \\
-2--2\end{array}$ & $\begin{array}{c}3.1 \\
-3.5-8.4\end{array}$ \\
\hline 19 T. neglectus & $\underset{*}{10} / 20$ & $\begin{array}{l}-3.4 \pm 0.5 \\
-4--3\end{array}$ & $\begin{array}{c}13.5 \\
8.4-22.0\end{array}$ & $\begin{array}{c}-4.6 \pm 0.8 \\
-6--4\end{array}$ & $\begin{array}{c}5.8 \\
-2.5-10.5\end{array}$ & & & & & & \\
\hline
\end{tabular}

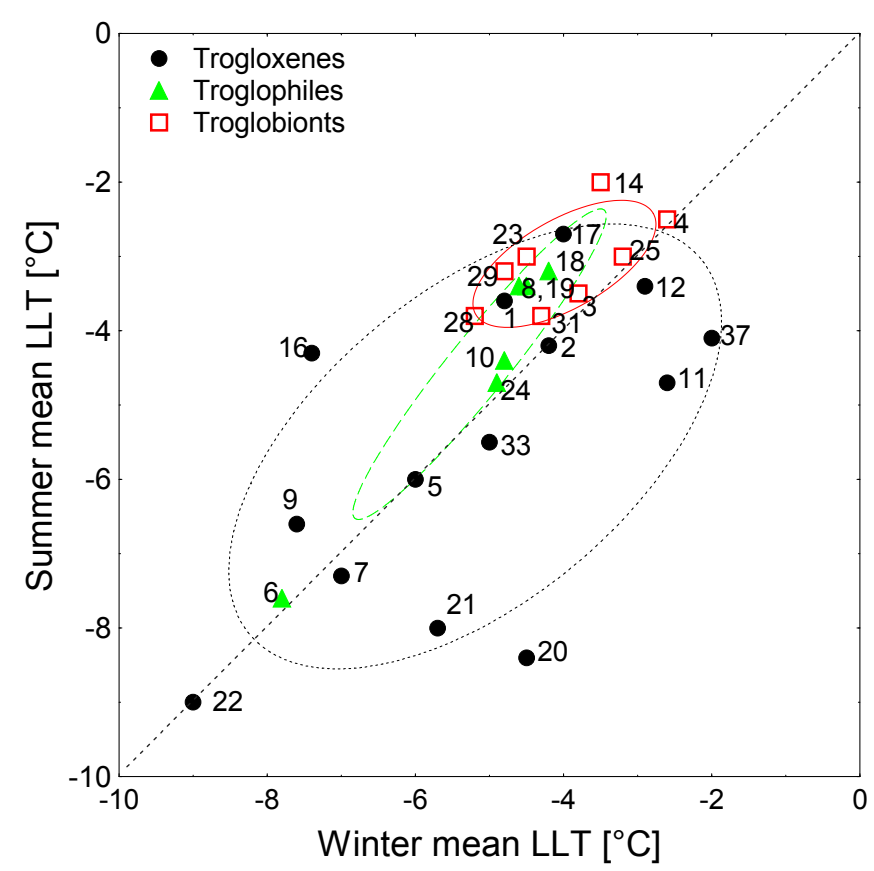

Fig. 1. Summer and winter mean LLTs in 28 species (current numbers as in Table 2) with both summer and winter data. The dotted line represents the balance axis between the summer and winter LLTs. subgroup, represented by Ischyropsalis hadzii, Anophthalmus hitleri, Ceuthmonocharis pusillus and $C$. robici robici, significantly enhanced their resistance to sub-zero temperatures in winter, lowering their $w$ LLTs at an average of $1.5^{\circ} \mathrm{C}$ with respect to the $s$ LLTs, while Andronuscus stygius, Titanethes albus, Aphaobiella tisnicensis and Leptodirus hochenwartii, classified in the deep subgroup, did not (Fig. 3). The species of the shallow troglobiont subgroup endured -2.0-$3.8^{\circ} \mathrm{C}$ in summer and $-3.2-5.2^{\circ} \mathrm{C}$ in winter, and the representatives of the deep troglobiont subgroup withstood $-2.5--3.8^{\circ} \mathrm{C}$ and $-2.6-4.3^{\circ} \mathrm{C}$, respectively. Between shallow and deep subgroup there was no statistical difference in s LLTs, while these differences were significant for $w$ LLTs (Mann-Whitney U test, $Z=3.55, \mathrm{p}<0.001$ ).

\section{Correspondence between the LLTs and caves temperatures}

In all the species under study the LLTs were lower than $\mathrm{T}_{\min }$ in the cave placements where the specimens occurred. There were no correlations between the LLTs and $\mathrm{T}_{\text {min }}, \mathrm{T}_{\text {mean }}$ and $\mathrm{T}_{\max }$ and the placement of these specimens in the caves. 


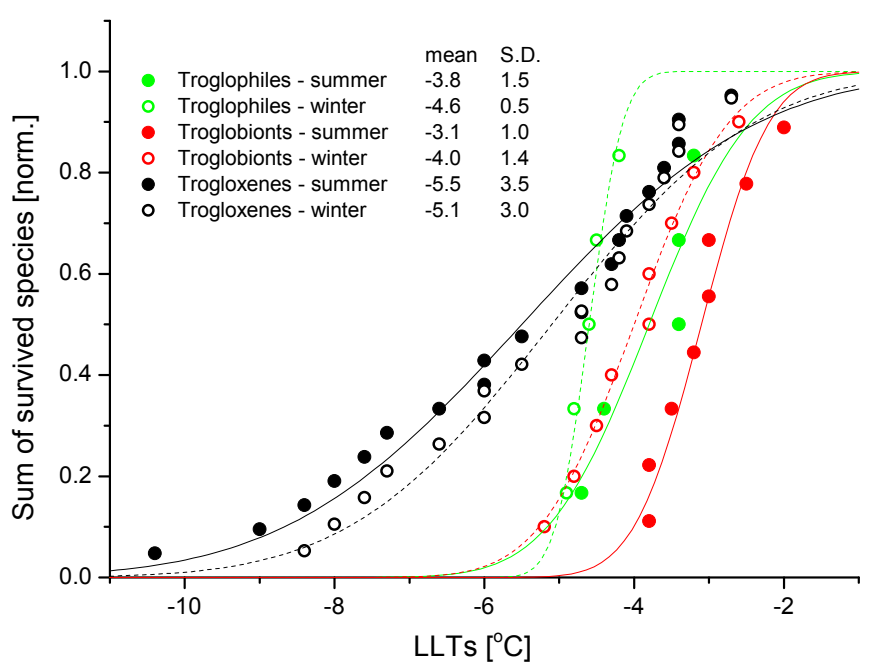

Fig. 2. Normalized distribution curves of LLTs in trogloxenes, troglophiles and troglobionts exposed to 12 -hr freezing intervals. The curves represent best fits to the error function to the data.

\section{DISCUSSION}

Multiple freeze-thaw cycles in a single winter are common in surface habitats in temperate latitudes and may present significant challenges to survival in insect species (Marshall \& Sinclair, 2011). While specimens in deep caves can effectively avoid extreme values, such conditions are expected widely in ice and other cold caves, the entrance cave sections and bedrock fissure systems connected with the surface and the SSHs (Gers, 1998; Růžička, 1999; Culver \& Pipan, 2009a, b; Růžička et al., 2013). Most frequently subfreezing conditions occur in winter conditions without snow, which is often caused by wind, especially the strong north-east wind, the bora (burja), with gusts of over $200 \mathrm{~km} \cdot \mathrm{hr}^{-1}$ (WineAndWeather, 2011) in the Dinaric region. The methodology used in our investigation simulated the repeated half-day frosts which occasionally affect the habitats of many species under study.

Cold resistance varies between and within species and depends on many factors, such as the developmental stage and age of an individual, its genetic potential, the season, the chill-coma temperature and the duration of exposure to low temperatures, nutrition, cold hardiness dynamics itself, diapause dynamics, photoperiodism, exposure to air currents, cryo-protective dehydration, the presence of nucleation agents and nucleation mechanisms, intracellular changes-such as mitochondrial disintegration, refreezing, experimental conditions etc., all these within the wide range of cryo-protection plasticity (Storey \& Storey, 1988; Leather et al., 1995; Sømme, 1999; Worland et al.,
2000; Block, 2002; Block \& Zettel, 2003; Ansart \& Vernon, 2003; Sinclair et al., 2003; Hodkova \& Hodek, 2004; Danks, 2006; Lagerspetz \& Vainio, 2006; Hawes \& Bale, 2007; Bowler \& Terblanche, 2008; MacMillan \& Sinclair, 2011; Vesala \& Hoikkala, 2011). The stepwise $1^{\circ} \mathrm{C}$-graded arrangement of our experiment does not allow precise determination of the LLTs; the real values may be, on average, about $0.5^{\circ} \mathrm{C}$ higher. On the other hand, although frequent freezing and rethawing is not painful to insects, it does cause permanent injuries, which in turn lower their ability to sustain low temperatures (Marshall \& Sinclair, 2011). Like SCPs, LLTs also depend on the duration of exposure to low temperatures; after long-term exposure, the organisms may die from the exhaustion of energy reserves (Renault et al., 2002). In our experimental species with low LLTs-mostly trogloxenes-these were probably underestimated because of many repeated refreezing and rethawing during the experimental procedure (cf. Marshall \& Sinclair, 2011). Gyas annulatus represents a special case among trogloxenes, showing no freezing tolerance in winter, which is the consequence of overwintering in water current-close, thermostated overwintering habitats (Novak et al., 2004). Speolepta leptogaster among troglophiles and Ischyropsalis hadzii among troglobionts are further cases of seasonal intolerance.

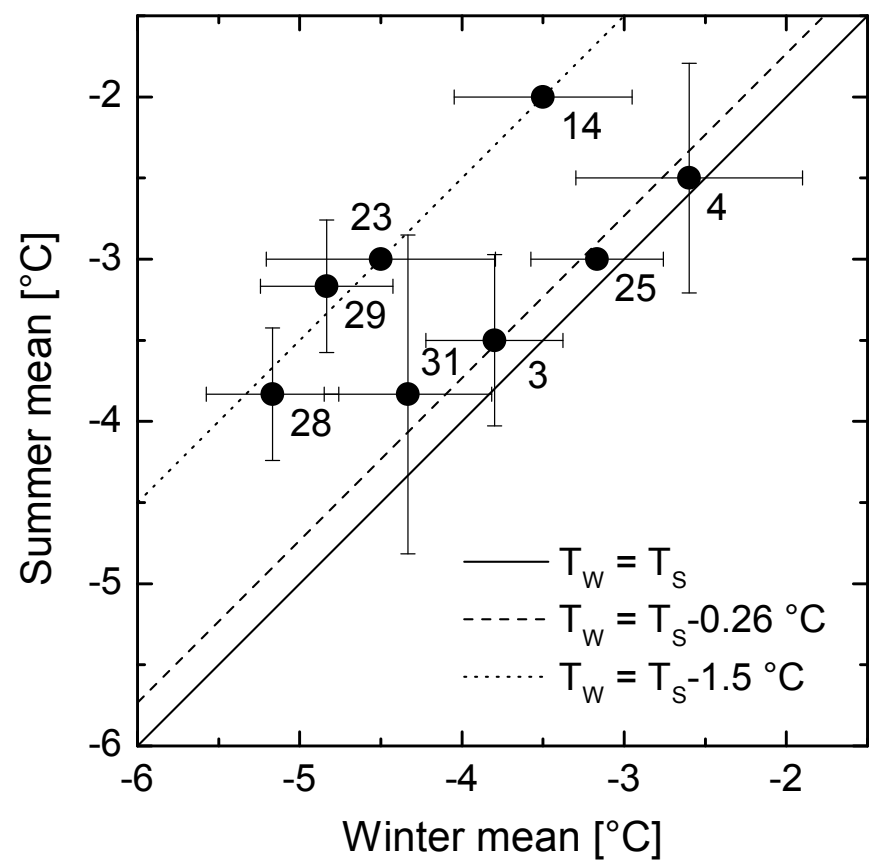

Fig. 3. Summer and winter mean LLTs of troglobionts (species numbers as in Table 2). Species 14, 23, 28, 29 belong to the shallow subgroup, species $3,4,25,31$ belong to deep subgroup. The solid line represents the balance axis between the summer and winter LLTs and dotted lines are guide to the eye for winter mean LLTs $\left(T_{w}\right)$, which are lower than summer mean $\operatorname{LLT}\left(\mathrm{T}_{\mathrm{S}}\right)$ for $0.26^{\circ} \mathrm{C}$ in the deep subgroup or $1.5^{\circ} \mathrm{C}$, respectively.

Table 3. Taxa exhibiting $\geq 1^{\circ} \mathrm{C}$ difference between the average summer and winter LLTs. The differences vs. the opposite season are in ${ }^{\circ} \mathrm{C}$ in brackets. Numbers in front of the names as in Table 2.

\begin{tabular}{|c|c|c|c|}
\hline The lowest $\mathrm{T}$ & Trogloxenes & Troglophiles & Troglobionts \\
\hline in summer & $\begin{array}{l}11 \text { Gyas annulatus }(-2.1) \\
20 \text { Triphosa dubitata }(-3.9) \\
21 \text { Scoliopteryx libatrix }(-2.3)\end{array}$ & 37 Speolepta leptogaster $(-1.9)$ & \\
\hline in winter & $\begin{array}{l}9 \text { Metellina merianae }(-1.0) \\
16 \text { Paranemastoma quadripunctatum }(-3.1) \\
17 \text { Trigoniophthalmus alternatus }(-1.3)\end{array}$ & $\begin{array}{l}8 \text { Meta menardi }(-1.1) \\
18 \text { Troglophilus cavicola }(-1.0) \\
19 \text { Troglophilus neglectus }(-1.2)\end{array}$ & $\begin{array}{l}14 \text { Ischyropsalis hadzii }(-1.5) \\
23 \text { Anophthalmus hitleri }(-1.5) \\
28 \text { Ceuthmonocharis pusillus }(-1.4) \\
29 \text { C. robici robici }(-1.6)\end{array}$ \\
\hline
\end{tabular}


Despite these problems, the overall responses of the 37 selected central European and Dinaric trogloxenes, troglophiles and troglobionts are comparable on the general level: lower a species sub-zero LLT, desto greater variability in individual LLTs. The species under study represent the expected general response to freezing: there is a clear decline in their LLTs from trogloxenes, to troglophiles and troglobionts. This is congruent with the general hypothesis of their increasing adaptation to the habitat.

Three troglophilic species deserve comment. The spider Troglohyphantes diabolicus is relatively common in the investigated caves (Novak et al., 2012), where individuals usually settle in wall fissures and recesses of up to $10 \mathrm{~cm}$ in diameter, and similar sized sites between stones and pits in the clay. For this reason, they frequently make webs over the pitfall trap orifices (authors and Slavko Polak's unpublished data). It has also been reported from small mammal burrows (Deeleman Reinhold, 1978) and water drips, which probably originate in vertical bedrock fissures (Pipan et al., 2008). This species thus prefers narrow subsurface habitats rather than caves, which is in agreement with its relatively high level of freezing resistance throughout the year, comparable to that for the trogloxenes. A second troglophic spider species, Meta menardi, is better adapted to the hypogean habitat than the similarly sized trogloxene Metellina merianae (Novak et al., 2010) and its average LLT fits into the troglophile range, and a few individuals showed the relatively high freezing resistance of $-8^{\circ} \mathrm{C}$. Such tolerance has been previously reported by Turquin (1971). Being also reported from screes (Růžička, 1999; Růžička et al., 2013) we support Růžička's suggestion that $M$. menardi is among species showing an intermediate stage in adaptation to the hypogean habitat.

In contrast, Speolepta leptogaster larvae show no cold resistance in winter. They mostly settle on ceiling and upper walls in caves emitting warm air. Such cave ceiling and blow holes, inaccessible to humans, form another thermally stable subterranean microhabitat, where temperatures generally do not fall below $0^{\circ} \mathrm{C}$ during winter. Like G. annulatus, $S$. leptogaster show moderate cold resistance in summer. Nearly all troglobionts under study showed a weak tolerance to below-zero temperatures. This is in accordance with Peck's (1974) and Leinconi et al. (2010) findings in other troglobionts. The investigated troglobionts responded in two ways and can be strictly differentiated with this respect. The species of the shallow troglobiont subgroup-Ischyropsalis hadzii, Ceuthmonocharis pusillus, C. robici robici, and Anophthalmus hitleri-were moderately resistant to freezing, enduring $1.5^{\circ} \mathrm{C}$ lower mean temperatures, in average, in winter than in summer. This seasonality clearly indicates their response to the winter external conditions which temporarily disturb their habitats, such as SSHs, by winter frosts.

The deep troglobiont subgroup-consisting of Androniscus stygius, Titanethes albus, Aphaobiella tisnicensis and Leptodirus hochenwartii-showed weak and nearly equal freezing resistance throughout the year. This subgroup appears to have adapted to the deep subterranean and any other subterranean habitat where freezing does not occur. Species carrying out its amphibious way of life, like Titanethes albus, known to submerge in water for long periods (Sket, 1986; Vittori et al., 2012), may avoid freezing in this way. Besides, species preferring the terrestrial phreatic environment ("milieu phreatique terrestre" sensu Jeannel, 1926), like Aphaobiella tisnicensis, are thermally buffered at abovezero temperatures (Novak et al., 2012). Such intolerance to freezing in terrestrial animals has been reported also from other close-to-water subsurface habitats, e.g., beside glaciers (Zettel, 2000), and between pebbles and stones near water streams (Novak et al., 2004).

\section{CONCLUSIONS}

Our study reveals that in central European and Dinaric trogloxenes, troglophiles and troglobionts, resistance to temperatures below $0^{\circ} \mathrm{C}$ generally decreases in accordance with their increasing adaptation to the hypogean habitat. Trogloxenes are most diverse in tolerance to sub-zero temperatures, from non-existent to high. Troglophiles are in between trogloxenes and troglobionts with this respect. Most troglobionts show moderate resistance to freezing, and are divided into the two identified ecological subgroups. Species of the first subgroup stand subzero temperatures significantly better in winter than in summer; this indicates that they most likely-at least temporary in winter-experience freezing in their preferred habitats. The second troglobiont subgroup responds more or less equally in summer and winter, which is considered a residual evolutionary tolerance. Both such responses appear also in troglophiles.

\section{ACKNOWLEDGEMENTS}

We are indebted to four anonymous referees for insightful comments on the manuscript, and to Michelle Gadpaille for valuable improvement of the language and Andrej Šorgo for discussion on statistical issues. We thank the Slovenian Environment Agency at the Ministry of Agriculture and Environment for permission to collect a limited number of selected protected subterranean species. This study was partly supported by the Slovenian Research Agency within the Biodiversity Research Programme (Grant No. P10078) and Infrastructure Programs of the Slovenian Research Agency (IP-0552).

\section{REFERENCES}

Ansart A. \& Vernon P., 2003 - Cold hardiness in molluscs. Acta Oecologica, 24: 95-102.

http:/ /dx.doi.org/10.1016/S1146-609X(03)00045-6

Block W., 2002 - Interactions of water, ice nucleation and desiccation in invertebrate cold survival. European Journal of Entomology, 99: 259-266. http://dx.doi.org/10.14411/eje.2002.035

Block W. \& Zettel J., 2003 - Activity and dormancy in relation to body water and cold tolerance in a winteractive springtail (Collembola). European Journal of Entomology, 100: 305-312.

http://dx.doi.org/10.14411/eje.2003.049 
Boutin C., 2004 - Organisms: classification. In: Gunn J. (Ed.), Encyclopedia of cave and karst science. New York and London (UK): Fitzroy Dearborn: 548-549.

Bowler K. \& Terblanche J.S., 2008 - Insect thermal tolerance: what is the role of ontogeny, ageing and senescence? Biological Reviews, 83: 339-355.

http://dx.doi.org/10.1111/j.1469-185X.2008.00046.x

Colson-Proch C., Renault D., Gravot A., Douady C.J. \& Hervant F., 2009 - Do current environmental conditions explain physiological and metabolic responses of subterranean crustaceans to cold? The Journal of Experimental Biology, 212: 1859-1868.

http://dx.doi.org/10.1242/jeb.027987

Culver D.C. \& Pipan T., 2009a - The Biology of Caves and Other Subterranean Habitats. Oxford University Press, Oxford, New York, 256 p.

Culver D.C. \& Pipan, T., 2009b - Superficial subterranean habitats - gateway to the subterranean realm? Cave and Karst Science, 35: 5-12.

Danks H.V., 2006 - Key themes in the study of seasonal adaptations in insects II. Life-cycle patterns. Applied Entomological Zoology, 41: 1-13. http://dx.doi.org/10.1303/aez.2006.1

Deeleman-Reinhold, C., 1978 - Revision of the cave-dwelling and related spiders of the genus Troglohyphantes Joseph (Linyphiidae), with special reference to the Yugoslav species. Opera SAZU, IV. cl., Ljubljana, $223 \mathrm{p}$.

Dessutter-Grancolas L., 1999 - Are troglobitic taxa troglobiomorphic? A test using phylogenetic inference. International Journal of Speleology, 26: 1-19. http://dx.doi.org/10.5038/1827-806X.26.1.1

Directive 2010/63/EU of the European Parliament and of the Council of 22 September 2010 on the protection of animals used for scientific purposes (Text with EEA relevance). Official Journal of the European Union, L 276/33, 20.10.2010.

Elster J. \& Benson E.E., 2004 - Life in the polar terrestrial environment with a focus on algae and cyanobacteria. In: Fuller B.J., Lane N. \& Benson E.E. (Eds.), Life in the frozen state. London: CRC Press: 111-150. http://dx.doi.org/10.1201/9780203647073.ch3

Field A., 2009 - Discovering statistics using SPSS (3 ${ }^{\text {rd }}$ ed.). London: Sage Publications.

Gers C., 1998 - Diversity of energy fluxes and interactions between arthropod communities: from Soil to Cave. Acta Oecologica, 19: 205-213.

http:/ /dx.doi.org/10.1016/S1146-609X(98)80025-8

Hawes T.C. \& Bale J.S., 2007 - Plasticity in arthropod cryotypes. The Journal of Experimental Biology, 210: 2585-2592. http://dx.doi.org/10.1242/jeb.002618

Hodkova M. \& Hodek I., 2004 - Photoperiod, diapause and cold-hardiness. European Journal of Entomology, 101: 445-458. http://dx.doi.org/10.14411/eje.2004.064

Hervant F. \& Mathieu J., 1997 - Respiratory adaptations in epigean and hypogean aquatic crustaceans. Memoires de Biospéologie, 24: 77-82.

Issartel J., Voituron Y. \& Hervant, F., 2007 - Impact of temperature on the survival, the activity and the metabolism of the cave-dwelling Niphargus virei, the ubiquitous stygobiotic $N$. rhenorhodanensis and the surface-dwelling Gammarus fossarum (Crustacea, Amphipoda). Subterranean Biology, 5: 9-14.

Kirchner W., 1973 - Ecological aspects of cold tolerance in spiders (a comparative study). In: Wieser W. (Ed.), Effects of temperature on ectothermic organisms: ecological implications and mechanisms of compensation. Berlin, Heidelberg, New York: Springer-Verlag: 271-279.

http://dx.doi.org/10.1007/978-3-642-65703-0_24
Latella P., Bernabò P. \& Lencioni V., 2008 - Distribution pattern and thermal tolerance in two cave dwelling Leptodirinae (Coleoptera, Cholevidae). Subterranean Biology, 6: 81-86.

Leather S.R., Walters K.F.A. \& Bale J.S., 1995 - The ecology of insect overwintering. Cambridge University Press, $255 \mathrm{p}$.

Lagerspetz K.Y.H. \& Vainio, L.A., 2006 - Thermal behaviour of crustaceans. Biological Reviews, 81: 237258. http:/ / dx.doi.org/10.1017/S1464793105006998

Lee, R.E., Jr., 2010 - A primer on insect cold-tolerance. In: Denlinger, D.L. \& Lee, Jr., R.E. (Eds.), Low Temperature Biology of Insects. New York: Cambridge University Press: 3-34.

http://dx.doi.org/10.1017/CBO9780511675997.002

Lencioni V., Bernabò P. \& Latella L., 2010 - Cold resistance in two species of cave-dwelling beetles (Coleoptera: Cholevidae). Journal of Thermal Biology, 35: 354-359.

http://dx.doi.org/10.1016/j.jtherbio.2010.07.004

Lipovšek S., Novak T., Janžekovič F., Senčič L. \& Pabst M.A., 2004 - A contribution to the functional morphology of the midgut gland in phalangiid harvestmen Gyas annulatus and Gyas titanus during their life cycle. Tissue and Cell, 36: 275-282.

http://dx.doi.org/10.1016/j.tice.2004.04.003

Luetscher M. \& Jeannin P.Y., 2004 - Temperature distribution in karst systems: the role of air and water fluxes. Terra Nova, 16: 344-350.

http://dx.doi.org/10.1111/j.1365-3121.2004.00572.x

Marshall K.E. \& Sinclair B.J., 2011 - The sub-lethal effects of repeated freezing in the woolly bear caterpillar Pyrrharctia isabella. The Journal of Experimental Biology, 214: 1205-1212.

http://dx.doi.org/10.1242/jeb.054569

MacMillan H.A. \& Sinclair B.J., 2011 - Mechanisms underlying insect chill-coma. Journal of Insect Physiology, 57: 12-20.

http://dx.doi.org/10.1016/j.jinsphys.2010.10.004

Novak T., 2005 - Terrestrial fauna from cavities in Northern and Central Slovenia, and a review of systematically ecologically investigated cavities. Acta Carsologica, 34: 169-210.

Novak T., Perc M., Lipovšek S. \& Janžekovič F., 2012 Duality of terrestrial subterranean fauna. International Journal of Speleology, 41: 181-188. http://dx.doi.org/10.5038/1827-806X.41.2.5

Novak T., Lipovšek S., Senčič L., Pabst M.A. \& Janžekovič F., 2004 - Adaptations in phalangiid harvestmen Gyas annulatus and Gyas titanus to their preferred water current adjacent habitats. Acta Oecologica, 26: 45-53. http://dx.doi.org/10.1016/j.actao.2004.03.004

Novak T., Tkavc T., Kuntner M., Arnett A.E., Lipovšek Delakorda S., Perc M. \& Janžekovič F., 2010 - Niche partitioning in orbweaving spiders Meta menardi and Metellina merianae (Tetragnathidae). Acta Oecologica, 36: 522-529.

http://dx.doi.org/10.1016/j.actao.2010.07.005

Peck S.B., 1974 - Biology of the Idaho lava beetle, Glacicavicola. National Speleological Society Bulletin, 36: 1-3.

Pipan T., Navodnik V., Janžekovič F. \& Novak T., 2008 - Studies of the fauna of percolation water of Huda luknja, a cave in isolated karst in Northeast Slovenia. Acta Carsologica, 37: 141-151.

Pullin A.S. \& Bale J.S., 1989a - Effects of low temperature on diapausing Aglais urticae and Inachis io (Lepidoptera, Nymphalidae): cold hardiness and overwintering survival. Journal of Insect Physiology, 35: 277-281. http://dx.doi.org/10.1016/0022-1910(89)90075-9 
Pullin A.S. \& Bale J.S., 1989b - Effects of low temperature on diapausing Aglais urticae and Inachis io (Lepidoptera, Nymphalidae): overwintering physiology. Journal of Insect Physiology, 35: 283-290.

http://dx.doi.org/10.1016/0022-1910(89)90076-0

Racovitza E.G., 1907 - Essai sur les problemes biospéologiques. Archives de Zoologie Expérimentale et Générale (Biospéologica I), 4e serie, 6: 371-488.

Renault D., Salin C., Vannier G. \& Vernon P., 2002 Survival at low temperatures in insects: what is the ecological significance of the supercooling point? Cryoletters, 23: 217-228.

Růžička V., 1999 - The first steps in subterranean evolution of spiders (Araneae) in Central Europe. Journal of Natural History, 33: 255-265. http://dx.doi.org/10.1080/002229399300407

Růžička V., Šmilauer P. \& Mlejnek R., 2013 - Colonization of subterranean habitats by spiders in Central Europe. International Journal of Speleology, 42: 133-140. http:/ /dx.doi.org/10.5038/1827-806X.42.2.5

Sacharov N.L., 1930 - Studies in cold resistance of insects. Ecology, 11: 505-517. http://dx.doi.org/10.2307/1929215

Schiner J.R., 1854 - Fauna der Adelsberger-, Lueggerund Magdalenen-Grotte. In: Schmidl A. (Ed.), Die Grotten und Höhlen von Adelsberg, Lueg, Planina und Laas. Wien: Braumüller: 231-272.

Sinclair B.J., Vernon P., Klok C.J. \& Chown S.L., 2003 Insects at low temperatures: an ecological perspective. Trends in Ecology and Evolution, 18: 257-262. http://dx.doi.org/10.1016/S0169-5347(03)00014-4
Sket B., 1986 - Isopoda: Oniscidea. In: Botosaneanu L. (Ed.), Stygofauna mundi: a faunistic, distributional, and ecological synthesis of the world fauna inhabiting subterranean waters (including the marine interstitial). Leiden: Brill E.J.: 482-485.

Sket B., 2008 - Can we agree on an ecological classification of subterranean animals? Journal of Natural History, 42: $1549-1563$.

http://dx.doi.org/10.1080/00222930801995762

Sømme L., 1999 - The physiology of cold hardiness in terrestrial arthropods. European Journal of Entomology, 96: 1-10.

Storey K.B. \& Storey J.M., 1988 - Freeze tolerance in animals. Physiological Reviews, 68: 27-84.

Turquin M.-J., 1971 - La faune de la grotte de Hautcourt (Ain). Sciences, 3: 145-154.

Vittori M, Kostanjšek R., Žnidaršič N. \& Štrus J., 2012 - Molting and cuticle deposition in the subterranean trichoniscid Titanethes albus (Crustacea, Isopoda). In: Štrus J., Taiti S. \& Sfenthourakis S. (Eds.), Advances in terrestrial isopod biology. ZooKeys, 176: 23-38.

Watanabe M., 2002 - Cold tolerance and myo-inositol accumulation in overwintering adults of a lady beetle, Harmonia axyridis (Coleoptera: Coccinellidae). European Journal of Entomology, 99: 5-9. http://dx.doi.org/10.14411/eje.2002.002

Wine and Weather.net, 2011. Archive for March $2^{\text {nd }}, 2011$ - http:/ / www.wineandweather.net/?m=20110302

Worland M.R., Block W. \& Grubor-Lajsic G., 2000 Survival of Heleomyza borealis (Diptera, Heleomyzidae) larvae down to $-60^{\circ} \mathrm{C}$. Physiological Entomology, 25: 1-5. http://dx.doi.org/10.1046/j.1365-3032.2000.00159.x

Zettel J., 2000 - Alpine Collembola: adaptations and strategies for survival in harsh environments. ZoologyJena, 102: 73-89. 